\title{
Regional Enlightenment in Transylvania: The educational reforms of Bishop Petru Pavel Aron, their influences and effects on the Uniate society in Transylvania in the Age of Enlightenment
}

\author{
MARIA IULIA FLORUTAU \\ School of Slavonic and East European Studies, University College London
}

The Transylvanian Enlightenment is a very contained phenomenon, yet fully fledged, attributed to a group of intellectuals in the last two decades of the eighteenth century known as the Transylvanian School. However, efforts towards Enlightenment appear much sooner, made possible by Uniate Bishop Inochentie Micu Klein's ideas and especially through the actions of his successor, Petru Pavel Aron. With the financial help of the Habsburg Empire, particularly that of Empress Maria Theresa, Bishop Aron created schools, a typography and an intellectual circle that established the foundation for the Transylvanian School. Largely under-researched, the Bishop's educational efforts will be examined in this study to argue that Enlightenment among the ethnic Romanian population appeared in Transylvania in a peripheral form forty years earlier than the Transylvanian School.

\section{Degrees OF ENLIGHTENMENT}

Any of the numerous studies on Enlightenment or Enlightenment-related topics conventionally begin by asserting the difficulties of defining the concept. Many of these studies may quote Immanuel Kant's famous definition that Enlightenment is "man's emergence from his self-imposed immaturity" 1 because it explains the shift in the mind-set of European civilization. Other definitions can be pertinent to most aspects of the phenomenon, such as Peter Gay's definition as "philosophes, [...] the totality of their ideas, their strategies, and their careers", ${ }^{2}$ one that is very helpful when considering the precise points of belief that changed and identifying their promoters. In opposition to this trickling-down definition, German philosopher

\footnotetext{
1 Immanuel Kant, What is Enlightenment, 1784 (online version http://www.english.upenn.edu/ mgamer/ Etexts/kant.html), accessed on 28 November 2012.

2 Peter Gay, Enlightenment, an Interpretation - The Rise of Modern Paganism (London: Weidenfeld \& Nicolson, 1967), pp xi-xii.
}

(C) School of Slavonic and East European Studies, University College London, 2014. 
Jürgen Habermas created a theory of Enlightenment that may be condensed as the public sphere (Öffentlichkeit), the idea that true change of civilization mind-set was a result of bottom-up processes inadvertently generated by (a part of) the masses throughout the eighteenth century. ${ }^{3}$ However, reaching beyond the classic idea of Enlightenment as French philosophes proposed new frames of reference for the world to the geographical areas in the Central and Eastern Europe or outside of Europe, new definitions are annexed to the general meanings contained by the aforementioned. Enlightenment in the European peripheries, a concept introduced by historians to designate phenomena of irregular or sporadic illuminations of less culturally advanced societies that can be connected to the Western European phenomenon introduces a focus on the particular, the nation, the ethnic or religious group or the geographical area. ${ }^{4}$ Western Enlightenment allows for cosmopolitan definitions of a philosophical movement; even if geographically, it spans over a triangular system of metropolitan France, England and the Netherlands. It allows Jonathan Israel, for example, to discuss the Spinozistic foundation of Enlightenment in a general manner. 'Peripheral' Enlightenment necessitates a national or regional enclosure because it is secondary; it is connected to the Western core in its own specific means that individualizes research. The geo-temporal area of this study, eighteenth-century Transylvania, does not connect with the 'core' in the same fashion that Austria, Russia and Prussia do, and because of this it is further removed. This raises the issue of whether forms of Enlightenment have penetrated the eastern province of the Habsburg Empire and whether they could genuinely be considered as belonging to Enlightenment. Furthermore, due to the multi-ethnic character of Transylvania - consisting of Hungarians, German Burghers, Seklars and Romanians alongside many other minorities, each separated within their own groups by religious differences-dissemination of Enlightened ideas is even more fragmented. For this reason, this article will focus on the Romanian-language Uniate community in the eighteenth century.

\footnotetext{
3 Habermas's theory identifies the bourgeois as carriers of change and connects it to his theory of communication as means of disseminating and driving this change. Jürgen Habermas, The Structural Transformation of the Public Sphere - An Enquiry into a Category of Bourgeois Society (London: Polity, 1989). ${ }^{4}$ Richard Butterwick, Simon Davies and Gabriel Sanchez Espinosa (eds), Peripheries of the Enlightenment (Oxford: Voltaire Foundation, 2008), p. 232.
} 
In Transylvania, the connection to the core becomes both abruptly and suddenly evident during the last years of the eighteenth century through the programmes and writings of the Transylvanian School, a group of Uniate clergy and intellectuals educated at the Uniate seminars. Historiography concerning the Transylvanian School is plenteous and far-reaching. Most historians connect the Enlightenment movement in Transylvania-iluminismul transilvănean-with the movement to emancipate the Romanians, made obvious by the Supplex Libellus Valachorum Transsilvaniae, a petition they had sent to Joseph II in 1791, explaining that the Romanians have a historical right, based on their prevalence in the region, to hold the same political and civic rights as the other nationalities. They are closely associated with Klein, a famous Uniate priest, who served as Bishop of Fagaras and Alba Iulia between 1730 and 1751.5 In 1739 and 1742, Klein convened the Transylvanian Diet at Blaj, the seat of the Uniate Church, attempting to obtain the recognition of the Second Leopoldine Diploma (19 March 1701), which gave the Uniates the same rights as the other religions. Failing to obtain political rights, Klein went to Vienna after Maria Theresa ascended the throne, remaining there for fourteen months and petitioning the Empress to obtain equal political rights for the Romanian Uniates. ${ }^{6}$

Between Klein's exile and the beginnings of the Transylvanian School in the last quarter of the eighteenth century, there is a significant gap of over thirty-five years. Most historians mention the three Uniate bishops that succeeded Klein - Petru Pavel Aron (1752-64), Atanasie Rednic (1765-72) and Grigore Maior (1773-82)when discussing the Enlightenment and the Romanians' fight for political rights, yet nobody attributes any significant enlightened features or emancipation programmes to any of them; they are mostly mentioned with the purpose of the continuity of the Uniate Church. The activity of one in particular, Aron, the mentee and successor of Klein, stands out as pertinent to the issue of peripheral Enlightenment.

The reason why this study will focus on his efforts towards education during his twelve-year tenure as bishop lies in the significance of his acts of creating an enlightened society within Transylvania. His achievements are largely overlooked

\footnotetext{
${ }^{5}$ Klein was exiled to Rome in 1741 by the decision of the Empress under the pressure of the Transylvanian Diet. Zoltán Tóth, Primul secol al naționalismului ardelean, 1697-1792 (Bucharest: Pythagora, 2001), pp. 142-53.

${ }^{6}$ Tóth (2001), pp. 112-17.
} 
and the development of enlightened ideas in the area is solely attributed to the Transylvanian School. However, they developed on an educational basis built before them, having had a significant number of schools and means of mass-printing their works and disseminating them in a growing, albeit very timid, public sphere. Historians of the School attribute the inspiration for it to Klein, but current scholarship does not explain the practical basis of their educational and literary activity from which they could derive their political activity. While Klein is significant for his work in vexing Vienna for political rights for Uniate Romanians on the grounds of the Leopoldine Diploma, he is not associated with important educational progress, perhaps because, while promoting the need for education among the Uniate Romanians, he was exiled before he could implement any programmes. Aron, on the other hand, actively pursued the founding of schools and founded a printing press in Blaj. After his death there were fifty-five registered schools ${ }^{7}$ and the students of those schools proceeded to become the intellectuals that formed that public sphere later in the century.

This study will demonstrate that the educational efforts of Bishop Aron are inscribed in the European Enlightenment phenomenon, albeit through several degrees of separation. While he is not a spearhead of the phenomenon and his written work focuses on doctrinal education, Aron's actions follow Klein's ideas on the creation of an educated society. Each of the educational measures taken by Aron, as well as his urgency and determination, was more evolved than Churchimplemented reforms and borrowed elements of the Enlightenment. They were essential for the creation of a public sphere in the area: the literary, historical and political activity of the Transylvanian School, and for the awakening of the Romanian society in the area between the end of the eighteenth and the beginning of the nineteenth centuries. Since Aron's activity has not been researched since Augustin Bunea's book in 1902, this study will make a curve through the information provided by the primary sources (the Bishop's educational activity, the founding of the schools in Blaj, the founding of the typography, and his interest in his alumni, while briefly discussing the influences of the emancipation doctrine, the

\footnotetext{
7 Augustin Bunea, Episcopii Petru Pavel Aron si Dionisie Novacovici (Blaj: Tipografia Seminarului Arhieodiecesan, 1902), p. 365.
} 
support he gained from the Jesuits, and his importance towards the formation of a public sphere) to illustrate that the basis of Enlightenment within the Transylvanian Romanian community lay the foundation for the formation of a more developed and advanced society.

\section{THE BISHOP}

Petru Pavel Aron was born in 1709 in Bistra, an area with a large population of converted Uniates, and stemmed from an ennobled family of priests and military officers. He studied at the Jesuit College in Cluj, was subsequently sent by Bishop Klein to study philosophy and theology in Rome, took the oath at the congregation Propaganda Fide on 26 May 1742, and was anointed a priest on 20 July 1743 by Uniate Bishop Dionisiu Modino, pledging that "quae ut compleam, superi auxilium praestent". ${ }^{8}$ In 1743, he returned to Blaj and became a vicar, but left for Vienna in 1744 with Klein, who trusted him to be his personal aide. He remained in Vienna for a year, until Empress Maria Theresa confirmed him as a vicar and he was sent to Blaj to coordinate the activity of the Church in Transylvania. He was named a bishop when the Empress called for an electoral synod in May 1751, where he was elected over two other candidates, and, by all accounts, the clergy was satisfied with the decision. ${ }^{9}$ On 28 February 1752, Maria Theresa officially instituted him as Bishop of Fagaras and Alba Iulia - the head of the Uniate Church in Transylvania - a role that he would keep until his death on 9 January $1764 .{ }^{10}$

Several historians' description of Aron as ascetic, while largely correct, is perhaps the product of his Jesuit education. However, his determination and efficiency are perhaps the traits of a utilitarian man, in the same spirit of Joseph II, who realized, as did his predecessors, that he had little time to make significant changes that were critically needed. Unfortunately, very little else can be said about his private life, except for the fact that he was a man of learning and a prolific writer, producing one book per year.

\footnotetext{
${ }^{8}$ Bunea (1902), p. 4.

${ }^{9}$ Bunea (1902), pp. 5-7.

${ }^{10}$ Arhivele Naţionale Române - Cluj, file 600, sheet 1272, Vienna, 28 February 1752.
} 


\section{The EMANCIPATION DoctRINE AND THE Founding OF THE SCHOOLS}

The introduction of the Uniate Church in Transylvania was the project of Count Leopold von Kollonitsch (1631-1707), ${ }^{11}$ Cardinal and Archbishop of Esztergom, who sought to widen Catholicism in the eastern provinces of the Habsburg Empire during the age of pietas Austriaca. The Decree of Unification was signed on 21 March 1697 by Orthodox Bishop Teofil of Alba Iulia, in an agreement similar to the ones prepared in the Commonwealth of Poland and Lithuania, therein keeping the majority of practices but accepting Papal authority. The most important terms were not religious, however, but political: members of the Uniate church had equal rights to the other four precept religions of Transylvania (Catholicism, Lutheranism, Calvinism and Unitarianism). The political rights were reinforced by the Leopoldine Diploma, issued by Emperor Leopold I on 4 December 1691, the act through which Transylvania was placed under Habsburg rule, and further detailed in the Second Leopoldine Diploma on 19 March 1701, when all Uniate peasants received full civic rights. ${ }^{12}$

The vast majority of Uniates were Romanian in ethnicity and had, until that point, the legal status of tolerated persons. There were only a few accounts of Romanian nobles, and most populations lived in significant backwardness by any standard of the late seventeenth and early eighteenth centuries, in small agrarian communities with almost non-existent literacy levels and no political representation. Creating a Uniate society and culture that was prepared to represent itself (and the Habsburgs in the Protestant Transylvanian society and politics) was a more challenging task than creating a Uniate Church, at the point of which the idea of the emancipation of Uniate Romanians appears. This idea does not originate with Klein, as it is often disputed in historiography, but a generally accepted idea formed in the beginning of the seventeenth century as a consequence of regional circumstances.

The Habsburg Monarchy and Archbishop Kollonitsch were among the first to recognize the need for education among the Uniates and began educating the priests, most of whom were as uneducated as their peasant parishioners, with the

\footnotetext{
${ }^{11}$ In Latin and Romanian language sources, Kollonich.

${ }^{12}$ Tóth (2001), pp. 13-34.
} 
goal of raising them from their 'schismatic' ignorance. ${ }^{13}$ Promising young men were funded by the state and educated in the Transylvanian Jesuit colleges, particularly at the College in Cluj, the capital. Future priests were expected to continue their education in Rome at the Collegium Germanicum et Hungaricum and subsequently, at the Collegium Graecorum et Ruthenorum. ${ }^{14}$ As in any lesser-evolved communities, the priests were the educators and influencers of their parishioners, and so their education as Uniate Catholics was vital.

The Transylvanian Protestants observed the lack of education among the Uniates and argued to the Crown that they could not accept Uniates in the Gubernium, despite the right to be represented at the level of the provincial institutions as conferred by the Leopoldine Diplomas, notwithstanding their high numbers, because they were uneducated, barbaric and unprincipled, and their nobles were few and of the lowest kind, unprepared for any profession. ${ }^{15}$

On the Uniates' side, Bishop Klein, although certainly not the first to recognize the need for progress among the members of his Church, was the most vocal advocate for their emancipation. Clashing with the Protestant-dominated Transylvanian Diet, which would not enforce the rights of the Uniates conferred by the Leopoldine Diploma and did not allow noble representatives of the Uniates in the Gubernium, Klein made the case, in one of the petitions sent to the Diet and the Crown in the same year, 1735, that the Uniates deserved the recognition of their rights by the other religions not simply in view of their numbers but also because they were sufficiently educated to participate in the running of the province. ${ }^{16}$

Probably the most significant influence in achieving the first Romanianlanguage school for the Uniates and the most underestimated was Empress Maria Theresa, who actively sought financial solutions for the building of a first Uniate school in Transylvania from the beginning of her reign. ${ }^{17}$ Viennese funding provided approximately forty thousand florins of the sixty-one thousand needed to build the

\footnotetext{
${ }^{13}$ Tóth (2001), p. 59.

14 Tóth (2001), pp. 58-60.

${ }^{15}$ Tóth (2001), pp. 89-90.

16 Augustin Bunea, Din Istoria Romanilor: Episcopul Inochentie Micu Klein (1728-1751) (Blaj: Tipografia Seminarului Archidiecesan, 1900), pp. 37-38.

${ }^{17}$ Tóth (2001), p. 233.
} 
cathedral, monastery and school complex in Blaj. The Empress actively encouraged all of Aron's educational pursuits, as well as the printing press. ${ }^{18}$

The matter of educating the Uniates, therefore, remains at the heart of the effort to weave them into a powerful society, as capable of being as involved in Transylvanian life and politics as any of the other four recognized religions. The issue on the minds of Kollonitsch and Klein was that, in order for the Uniates to rise to this challenge, they needed to be pulled out of the ignorance and backwardness in which they were living and educated through every means available in the region, restricted to religion as they were. Education lies at the heart of any enlightened movement, whether at the 'core' or the 'peripheries', and it was imperative in Transylvania in order to create a basis for a society that was seen as buried in 'darkness'.

Education during the first five decades of the eighteenth century evolved slowly but achieved some progress among the clergy, primarily through the Jesuit colleges, which prompted Klein to claim that the Uniates had enough educated people from whom they could choose members of the Gubernium. However, within Uniate circles, Klein acknowledged that far more needed to achieve this in order to improve instruction within the Church. At the 1738 Synod in Blaj, convened and administered by him, ${ }^{19}$ Klein raised the question of building the first Romanianlanguage school in Transylvania. ${ }^{20}$ The building of the new school's complex commenced soon after and was largely completed by 1747, though it was only opened on 18 October 1754, after Aron had been officially named a bishop. Bunea provides an account of the school structure after the first two months of existence: the complex contained three schools, organized as levels depending on the student's needs: scoala de obste (public school), which any pupil could attend, teaching reading, writing and mathematics, which, according to a source, had existed from 1738, ${ }^{21}$ which began with seventy-nine students; scoala latinească (the Latin school), teaching Latin, Hungarian and sciences, starting with seventy-four students; and scoala de

\footnotetext{
${ }^{18}$ Tóth (2001), p. 232.

${ }^{19}$ Bunea (1900), p. 3.

${ }^{20}$ In the seventeenth century, a school in Brasov, a Transylvanian city on the Carpathian border with Wallachia, had Romanian teachers, who wrote a few manuscripts in Cyrillic on the study of theology, but very little is known of them. Nicolae Albu, Istoria invățământului românesc din Transilvania până la 1800 (Blaj: Lumina, 1944), pp. 52-53.

${ }^{21}$ Tóth (2001), p. 311.
} 
religiune (theological school), teaching theology and opening with twenty-five students. The students of the second school had to attend the first school as well, and the students of the third school - the ones that would go on to attend the seminary were obliged to attend the first and second. In 1754, the total number of students was 178 , twenty of whom were also boarding in the complex.22 By 1759, five hundred students attended, encouraged by the meals provided by the bishopric, ${ }^{23}$ a programme which continued throughout Aron's tenure. ${ }^{24}$ In 1772, under Bishop Rednic, Aron's successor, the schools would teach philosophy, rhetoric, logic, and ethics. 25

A scholastic calculus from 1755, made a year after the school was opened, presents supplementary information on the enrolled students. ${ }^{26}$ Eighty-two students are listed in four tables, divided into four categories: majores (fourteen students, aged 14 to 20), minores (forty students, aged 10 to 21 but mostly 14 and 15), mediocres (twelve students aged 8 to 18 but mostly 9 or 10) and minimis (sixteen students aged 4 to 12); judging by the students' ages, the categories most likely refer to the grade group in which they belong. The age extremities of each group do not seem to be formalized, with 1755 being the first year of the school's existence, which indicates that an exam was used to separate the children into the categories. Although, the school was open to any age, as evidenced by the wide age range-between four and twenty-one. The relatively old age of the students in each category was not unusual for Uniates, who would begin their education around the age of ten. Another column indicates the exams and the month in which the children took themdeclinationes, conjugationes and $A, B, C$-which conveys that the exams were based on the ability to read and write at the lower levels, and knowledge of Latin grammar at higher levels. The majores had all mastered the declinations, whereas the mediocres and minores had passed a combination of the latter two. No exam was imposed on the minimis, which suggests that the class was intended to teach reading and writing.

\footnotetext{
${ }^{22}$ Bunea (1902), pp. 278-79.

${ }^{23}$ Bunea (1902), p. 283.

${ }^{24}$ The Rector of the schools, Atanasie Rednic, wrote to Aron requesting funds for meals for the new school year. ANR-CJ, 600/382, Blaj, 18 November 1762.

${ }_{25}$ Bunea (1902), p. 286.

${ }^{26}$ Calculus Scholasticor Anni 1755. The fields of the table are: nomen et cognomen, genus et conditio, patria et comitatus, atas (sic), lvando? et ad quid, cujus profectus, cujus spei. ANR-CJ, 600/200, Blaj, 1755.
} 
The children came from the counties near Blaj, which fell under the jurisdiction of the Bishopry of Fagaras and Alba Iulia, but the majority came from the county of Albensis (now Alba), in which Blaj was located, demonstrating that proximity played a significant part in the children's attending the school. The ethnicity of the students is hard to tell due to the fact that some Romanians had magyarized names drawn from the name of their home village or area, but both Hungarian and Romanian surnames appear alongside the Latinized first names, perhaps hinting that Hungarian Catholics attended the school. Their social status varies widely and, again, conveys that the school was open to any student: some were free men (Libertinus), secular nobles (nobilis secularis), ecclesiastical nobles (nobilis Popa fillius), children of regular clergy (libertinus Popae filius), and two low plebeians, possibly serfs ${ }^{27}$ (Subditu Plebeju), as well as four ingenus Popa fillius, which could perhaps refer to the sons of the higher educated clergy. Slightly more than half were children of priests, as the Uniate church preserved the requirement of the regular clergy to marry, which shows that clergy would be most interested in educating their children. However, the significant number of free men and nobles indicates that education among the Uniates is spreading beyond the ecclesiastical circles as more Uniate families are ennobled.

The scholastic calculus of 1755 differs in information from Bunea's dating from December 1754, which could indicate that the calculus refers to only one of the schools above, either the public or, more likely because of the mention of the Latin grammar exams, the Latin school. Nevertheless, the information in the calculus reveals the administrative and social structure of the schools and their openness to receiving any students.

Students would enrol by sending a written request to the Bishop himself requesting the "right to follow school",28 and this right appears to be open to anyone, regardless of region, as students from Banat or Wallachia solicit enrolment. ${ }^{29}$

\footnotetext{
${ }^{27}$ In 1746 Maria Theresa granted the children of the Uniate serfs the right attend school. ANR-CJ, 600/92, Vienna, 16 April 1746.

${ }^{28}$ ANR-CJ, 600/275, 1758; 600/294, 16 April 1759.

${ }^{29}$ ARN-CJ 600/294, 16 April 1759.
} 
It was also Aron who decided which students could proceed to study in Rome and on whose authority the decree to send and fund them was signed. ${ }^{30}$

The school's teachers were Aron's colleagues from the Jesuit College in Cluj, who possessed an education similar to his; set in Vienna or Rome, among them were Atanasie Rednic (Aron's successor as bishop), Gregorie Cotonea, Grigore Maior (who followed Rednic as bishop), and Silvestru Caliani. The other teachers were monks from the Blaj monastery, which was housed in the complex. There is no indication of how the teachers were appointed in the schools, whether in Blaj or in the counties, during Aron's tenure, although later they would be named through an educational commission.

At the beginning of Rednic's tenure, he enumerated fifty-five schools across the Transylvanian province. ${ }^{31}$ The census-made at Aron's request in October 1750 - shows that there were 554,149 Uniates, ${ }^{32}$ which conveys a rather troublesome ratio between the probable number of children of school age, schools and raising literacy levels. All schools were built in larger villages that served as centres for the communities around them. The curriculum was similar to the public school in Blaj, teaching reading, writing and numeracy in Romanian by the ludi magistri, a function that in some cases was performed by the local priest, whose level of education could be dubious. During the last decades of the eighteenth century, teachers in the villages would be better prepared to teach, having had the opportunity to study in Blaj and at the university in Cluj or in other parts of the Empire. The buildings are not mentioned, but it may be assumed that the schools were founded in the Churchowned buildings, since the author of this study found no evidence of funding towards purposely-built schools. Aron's tenure would not have been long enough to erect many new constructions. No attendance and/or graduation certificates have remained, if the village schools did issue them during Aron's tenure. Uniates continued to attend the Jesuit colleges after the schools in Blaj opened, as evidenced by the Romanian names on the graduation certificates. ${ }^{33} \mathrm{~A}$ member of the Aron family, Nobilis Joannes Aron-most likely one of his nephews-graduated from the

\footnotetext{
${ }^{30}$ ANR-CJ, 600/355, Blaj, 23 August 1761.

${ }^{31}$ The full list in Bunea (1902), pp. 365-66.

${ }^{32}$ Bunea (1900), Annex XI, pp. $418-19$.

${ }^{33}$ Certificate of Graduation for Joannes Pop from the Jesuit College in Odorhei. ANR-CJ 600/376, Oradea, 9 September 1762.
} 
Jesuit College in Cluj in 1757, ${ }^{44}$ which signifies that the wider Aron family had been ennobled and that a tradition had formed within the now-titled family to have the children sent to Jesuit colleges, despite the fact that Bishop Aron had recently opened a seminary in Blaj. It is therefore likely that some of the children of the wealthier families that had been ennobled by the Habsburgs would generally continue to attend the Jesuit seminaries in the larger urban centres such as Cluj or Târnava. No women are ever mentioned in any of the education-related documents consulted from the eighteenth century.

Regardless of the obvious shortcomings, this is a very swift and impressive progress achieved in less than twelve years. Its significance for Transylvanian Enlightenment lies not in the building of seminaries, which is a normal ecclesiastical course of action for any Christian Church in any century, but in the establishment of schools for the laity with the specific purpose of raising an entire nation out of its own darkness. It is also one that is remarkably open to any student of any age and class, which reinforces the Uniate leaders' wish to form a society of educated people that were capable of participating in and contributing to the Transylvanian political and economic life.

The emancipation doctrine, which by the mid eighteenth century had an enlightened feature, would gain political character at the century's end, when the members of the Transylvanian School, who by then would be observing over a significantly more educated Uniate society, would petition for rights for all Romanians. The used argument regarded numbers, thereby asking for proportional representation in the Diet, which would have meant a majority stake in the region's political body.

\section{THE JESUIT INFLUENCE}

The Jesuits, the papacy's missionary spearhead in its Counter-Reformation efforts, reverted to Cluj in 1693, once Transylvania was returned to Habsburg rule, and

\footnotetext{
${ }^{34}$ ANR-CJ, 600/228, Cluj, 19 July 1757.
} 
remained there until the Society was suppressed in 1773. ${ }^{35}$ Their activity is closely related to that of the Empire and its efforts to Catholicize Protestant Transylvania. Their presence was directly supported by Vienna. Moreover, with the Habsburgs aware of the fact that there would be very few converts among the recusant Protestants, the Jesuits' efforts were to be concentrated on the Uniate Church, which had far better chances of gathering converts from the Orthodox population through the offering of political rights. ${ }^{36}$ Hence, the connection between the order and the Uniate Church was very close and the first offered support in all areas, especially in education to the latter, encouraged and funded by Archbishop Kollonich of Esztergom, the Archbishop of Hungary.

The substantial extent of Jesuit influence in the Uniate Church's educational programmes begs the question of whose influence-Jesuit or enlightened-prevailed over Aron and the Uniates' educational programmes. What is the extent of each influence? Firstly, almost all Uniate bishops, including Klein and Aron, were educated in the Collegium in Cluj and then subsequently studied in Vienna or in Rome at Propaganda Fide. ${ }^{37}$ Secondly, Zoltán Tóth argues that the true foundation of Romanian emancipation lies in the ground-breaking educational advances that the Jesuits made. His theory emphasizes the fact that the Romanian Uniate leaders, conscious of the primitive state of their religious group, drew inspiration from their immediate vicinity, namely from the Calvinist colleges, where the first Uniate bishop, Athanasie Anghel, was educated and, a few years later, almost exclusively from the Jesuits. 38

The Jesuit influence was also sensed in architecture. The two most significant examples, built in the first half of the century, are the Holy Trinity Cathedral and the building complexes surrounding it. In 1738, the first was commissioned by Klein, who had employed the Viennese architect Johann Martinelli. Aron added the façade, as evidenced in this study, which was covered financially by the Imperial Court. Aron was also the bishop that inaugurated the cathedral in 1756. The complex was constructed between 1731 and 1747, first intended to house a monastery, though

\footnotetext{
${ }^{35}$ Paul Shore, Jesuits and the Politics of Religious Pluralism in Eighteenth Century Transylvania, Culture Politics and Religion, 1693-1773 (Burlington: Ashgate, 2007), p. 7.

${ }^{36}$ Shore (2007), pp. 55-62.

${ }^{37}$ Tóth (2001), pp. 59-61.

${ }^{38}$ Tóth (2001), pp. 53-54.
} 
Aron opened the first Romanian-language school instead in $1754 .{ }^{39}$ The cathedral is almost identical to the Jesuit Basilica in Cluj, while the building complex that housed the school resembles the Cluj Jesuit seminary complex. The cathedral's exterior is therefore built in the baroque style with high arches and pear-shaped domes, as are used in Central European architecture, evidently bearing no resemblance to the Byzantine influences used in Orthodox churches, although the interior carries such elements in the altar. Both Klein and Aron were educated in Cluj and spent their formative years in the aforementioned buildings, which irrevocably influenced their image of an educational space. The architecture is also indicative of the religious roots that educational pursuits had for Romanians, so much that even the efforts to establish lay education carried the mark of the Jesuit system in the Age of Catholic Enlightenment.

The relationship between the Jesuits and the Uniate bishops was not entirely cordial, because of the institution of the theologian, a Jesuit monk placed by the Habsburgs to aid in theological matters, but whom the bishops saw as an unwelcome foreign control. All bishops, including Klein and Aron, repeatedly petitioned to Maria Theresa in the hope of his removal, but she refused to do so. The institution was ultimately abolished when the Jesuits were expelled in $1773 .{ }^{40}$

It is therefore very difficult to determine how much of the educational policies were of Jesuit influence and how much was influenced by European Enlightenment, particularly with Bishop Aron, and the line between the two influences shifts as each element is introduced to the debacle. However, the Jesuit influence was felt on a smaller, particular level, in the way Aron structured and administered the schools in the monastery complex, but the need for education for the Uniate Romanians formed a much larger-scale project that was incorporated into the enlightened Habsburg policies of Maria Theresa.

\footnotetext{
${ }^{39}$ Marius Porumb, Catedrala Sfanta Treime Blaj la 1751, Acta Musei Napocensis, Cluj, 32/1995, pp. $353-57$.

${ }^{40}$ Bunea (1902), pp 11-16.
} 

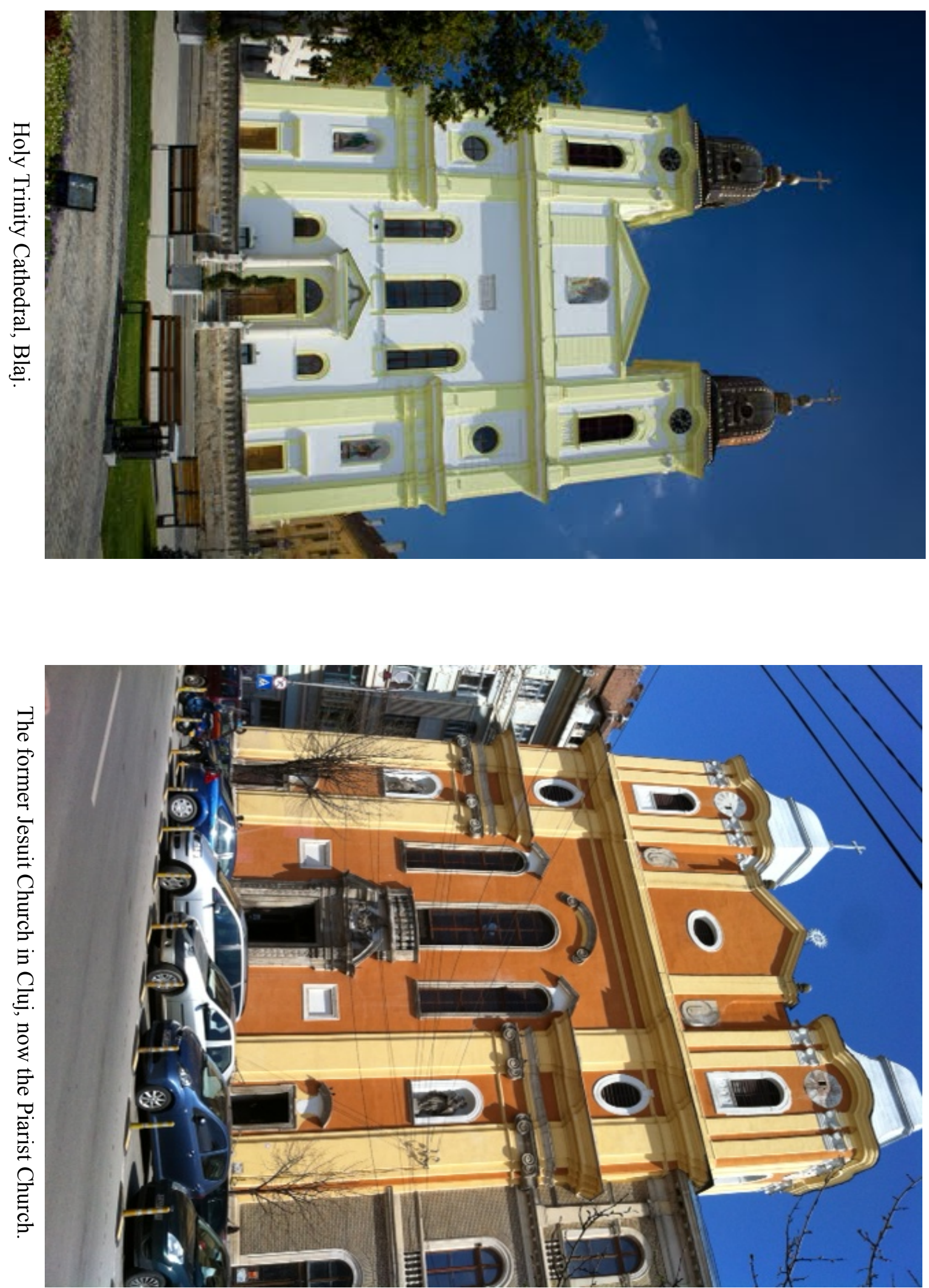

(C) School of Slavonic and East European Studies, University College London, 2014. 


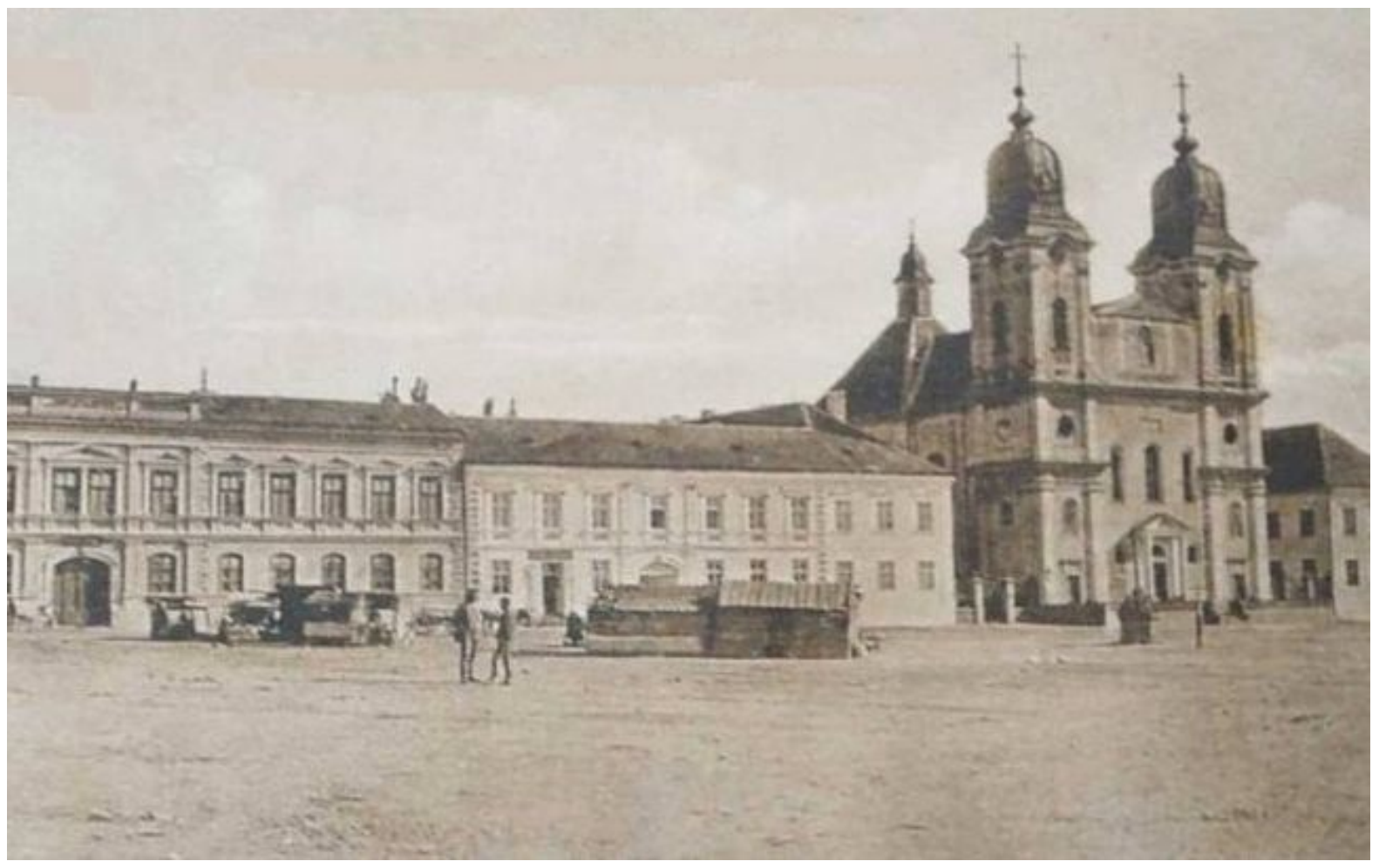

Blaj Cathedral and façade of the school complex (middle).

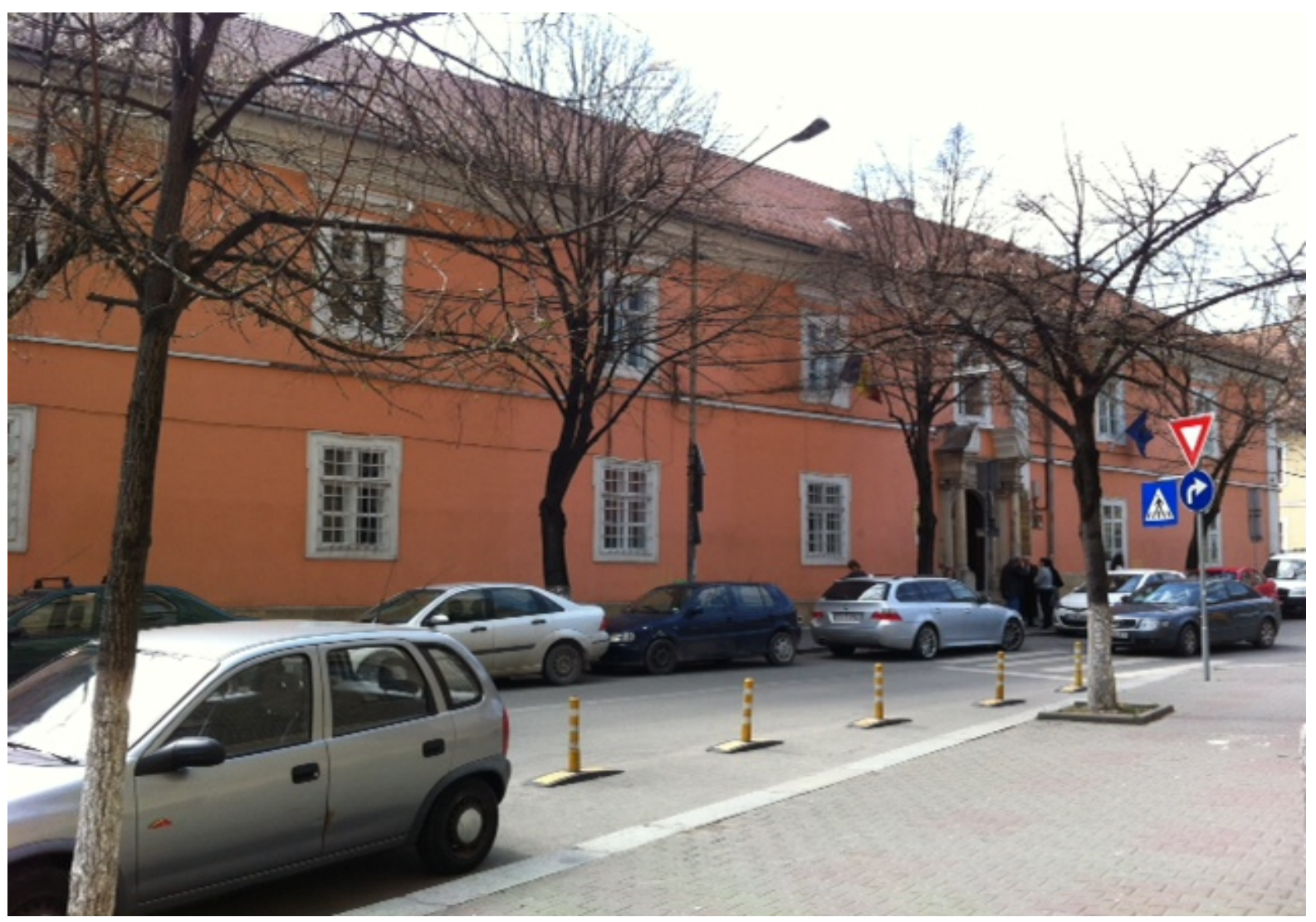

The former Jesuit College, Cluj.

(C) School of Slavonic and East European Studies, University College London, 2014. 


\section{The Public Sphere}

Enlightenment in Transylvania is a top-down phenomenon. Habermas's theory of public sphere cannot be convincingly applied before the beginning of the nineteenth century, when cultural movements begin to appear beyond Blaj and Cluj in other urban centres in Transylvania and Banat, ${ }^{41}$ particularly Oradea. ${ }^{42} \mathrm{~A}$ bourgeois-rooted public sphere that would match what Habermas had in mind appears in the 1830s. ${ }^{43}$ However, the Romanian secular intellectual circles remained Uniate and of noble origin. 44

The lack of a consistent public sphere can be seen from the letters addressed to Aron during his tenure as bishop. The vast majority concerned either naming a particular priest in a parish ${ }^{45}$ or requests for Aron to intervene in estate trials, ${ }^{46}$ marital conflicts ${ }^{47}$ and economic issues, ${ }^{48}$ and so forth. In the years preceding the 1760 Orthodox insurrection, there are also letters from Uniate priests that attest to the conflict with the Orthodox population. ${ }^{49}$ The letters suggest that Aron had the legal authority to resolve conflicts in matters of the Church, as well as to mediate with the authorities or the nobility on whose estate the conflict had arisen, indicating the Bishop's legal role and influence. However, even after schools are founded in villages, the letters do not change in character and do not concern educational matters. Moreover, most of these letters are very short and fewer in Latin, most being in Romanian (written in Cyrillic script) or Hungarian. Some are written on behalf of parish priests by the Hungarian nobility, whose estate was near or included the parish, ${ }^{50}$ suggesting that those priests were illiterate. Most of the priests had converted from Orthodoxy and were educated through a form of apprenticeship by the parish priests. The roles were often inherited.

\footnotetext{
${ }^{41}$ Prodan (1967), p. 415.

${ }^{42}$ Tóth (2001), p. 335.

${ }^{43}$ Zsuzsanna Török, The Friends of Progress: Learned Societies and the Public Sphere in the Transylvanian Reformed Era, Austrian History Yearbook, 2005, vol. 36, pp. 97-104.

44 Tóth (2001), p. 339.

${ }^{45}$ ANR-CJ, 600/222-223, Bia, 12-13 June 1957; 600/213, no place, 5 June 1757; etc.

${ }^{46}$ ANR-CJ, 600/211, 25 May 1782.

${ }^{47}$ ANR-CJ, 103/62, sheet unnumbered and undated, 600/238, Sibiu, 17 December 1757; etc.

${ }^{48}$ ANR-CJ, 600/251, Șona, 26 April 1758.

${ }^{49}$ ANR-CJ, 600/293, Sibiu?, 13 April 1759.

${ }^{50}$ ANR-CJ, 600/249, Viile Tecii, 9 April 1758.
} 
The fact that the letters' subjects do not change from the beginning of the century illustrates that there were significant gaps in the education of Uniate priests. The only correspondence Aron had on matters of education with other members of the Uniate Church are with the high-ranking priests; Atanasie Rednic, the rector of the Uniate Seminary in Blaj who would succeed him as bishop; Gherontie Cotonea, the Prefect of the printing press ${ }^{51}$ and author of the Uniate catechism (1756-57); and a few other teachers from the Blaj schools, such as Grigore Maior, another future bishop, who writes to Aron in regards to the creation of a Lexicon for the schools, ${ }^{52}$ and Ladislau Mosa. ${ }^{53}$ All these men, like Aron himself, had been educated at the Cluj Jesuit College, followed by Rome and Vienna. All are involved, to a large degree, in Aron's plans and programmes for education. Moreover, Rednic and Maior would continue all of Aron's educational programmes. The fact that the few men within the Uniate Church can constitute a very narrow public sphere that is centred around the Bishop's educational pursuits suggests the importance of education for the Church's advancement (in the case of the two teachers, Rednic and Maior, who later became bishops), as learning provides a profession and a social status just as important, if not more so, than a separate ecclesiastical career. Therefore, education itself becomes as central to the Uniate Church as the propagation of faith; the former has the distinction of having a significantly secular character and aim, because of the focus on the Church's lay members and the goal of providing a self-sufficient lay society, in addition to the fledging religious sphere.

Regardless of the bleak public sphere, Aron quickly made progress on an otherwise non-existent foundation. The generations that benefited from his schooling programme in the sixth and seventh decade of the century were the ones that formed the basis of the Transylvanian public sphere. Towards the eighteenth century's end, the correspondence in educational matters appears for the first time and intensifies, with lay teachers from schools all over Transylvania writing to Ioan Bob, representative of the Transylvanian School and bishop between 1783 and 1830,

\footnotetext{
${ }^{51}$ ANR-CJ, 600/176, Blaj, 28 October 1756.

${ }^{52}$ ANR-CJ, 600/312, Blaj, 2 November 1759.

${ }^{53}$ ANR-CJ, 600/270, Dej, 1 December 1758.
} 
asking in particular for support for excellent students who should be helped financially to continue their education in Blaj. ${ }^{54}$

Furthermore, two elements developed by Aron contribute to the emergence of a public sphere in later decades, specifically the first Uniate printing press in Blaj, founded in 1754. Secondly, the support given to the alumni of the Blaj colleges who studied abroad. This formed the pool from which the future teachers and clergy would be chosen.

A press printing Romanian-language books had existed since the early seventeenth century, founded by György Rákóczi I, a Transylvanian prince, and was used to edit catechisms. The printing press itself was moved to Alba Iulia and lay disused until bishop Aron moved it to Blaj. Aron twice purchased new parts for it in an attempt to modernize it for future intensive use. ${ }^{55}$

Gherontie Cotonea, who belonged to the higher clergy educated in Rome and Vienna and who was a former colleague of Aron's in the Jesuit College, was the Press Prefect, who had the authority to approve costs and activities, although it does not seem he was more involved in the running of the press than in matters of supervision. The date when Aron appointed him to this position is unknown. Aron was still involved in the press's running. However, when the press was damaged, Aron was informed immediately that funds were needed for its repair. ${ }^{56}$ Gherontie Cotonea also kept Aron informed of the situation of the press, informing the Bishop that it was running smoothly. ${ }^{57}$

Later, the press would be used for printing imperial decrees and patents of concern to the Uniate Church, 58 and the Gubernium would use it to translate into Romanian decrees issued by them ${ }^{59}$ or by Vienna, ${ }^{60}$ and print them, illustrating its growing importance for disseminating information, official or not, within the Uniate society. Moreover, as the schools' educational levels in the counties grew, the press began to be used for educational material. In 1785, two teachers in Ocna Dej-a

\footnotetext{
${ }^{54}$ ARN-CJ, 600/808, Sibiu, 30 August 1802.

${ }^{55}$ Bunea (1902), pp. 352-55.

${ }^{56}$ ANR-CJ, 600/353, Blaj, 3 June 1761.

${ }^{57}$ ANR-CJ, 600/366, Blaj, 6 February 1762.

58 ANR-CJ, 600/494, Blaj, 24 February 1768; also a document calculating the costs of publishing imperial rescripts: ANR-CJ, 600/502, 1768.

${ }^{59}$ ANR-CJ, 600/492, Sibiu, 2 February 1768.

${ }^{60}$ ANR-CJ, 600/473, Sibiu, 22 November 1766
} 
small locality near Cluj-wrote a standard request to collect their unspecified teaching material from the Blaj press, ${ }^{61}$ establishing a direct connection between the press and the schools' regular educational efforts. According to Bunea, the books printed during Aron's time as bishop were mostly theological; alas a list does not remain. ${ }^{2}$ On this note, Tóth mentions that Aron formed the first library with the 254 books left by Bishops Pataki and Klein. It was supervised and enlarged by Maior, and significantly expanded by a donation from Maria Theresa, but a list of the first books does not remain; they were presumably mostly theological. ${ }^{63}$

As for the Blaj alumni, 64 they are one of the preponderant themes of Aron's preserved letters, with yearly letters from different officials and cardinals ${ }^{65}$ in Rome (Collegium Germanicum et Hungaricum, Collegium Graecorum et Ruthenorum and Propaganda Fide) and Vienna (Pazmaneum and University of Vienna ${ }^{66}$ ) and even cordial correspondence from the alumni themselves ${ }^{67}$ In the interest of brevity, the content of the letters will not be analysed, but it concerns mostly the evolution, discipline and funding of the students, and evidences the care and special interest that Aron took to prepare the next generation of Uniate intellectuals. Furthermore, the fact that an extensive part of the Bishop's correspondence with the Vatican focused on alumni is indicative of the relationship between them. While the Vatican was not directly involved in the lay educational efforts of Aron, they were involved in training the priests that came from Blaj, which makes the relationship with the Vatican particularly important to the development of future teachers and educated clergymen that could efficiently administer the Church and its activities.

The education of the alumni was funded by foundations, trusts of money supplied by the Church, the Vatican, and Vienna in varying proportions. The costs of sending them abroad were very high: in a letter to Aron, Silvestru Caliani informs him of two alumni whose costs for their education in Rome (the length of which is not mentioned but usually lasted two or three years), paid through the fundatione,

\footnotetext{
${ }^{61}$ ANR-CJ, 600/681, Ocna Dej, 26 August 1785.

${ }^{62}$ Bunea (1902), p. 355.

${ }^{63}$ Tóth (2001), p. 245.

${ }^{64}$ The term seems to refer specifically to the students receiving scholarships for higher education.

${ }^{65}$ ANR-CJ, 600/389, Blaj, 1762; 310, Rome, 1762; etc.

${ }^{66}$ ANR-CJ, 600/375, Vienna, 2 September 1762.

${ }^{67}$ Thee alumni inform the Bishop on their itinerary and impressions of Rome. ANR-CJ, 600/359, Rome, 26 November 1761 .
} 
were 473 and 372 florins per year, respectively. ${ }^{68}$ Comparatively, the sums Maria Theresa sent to Aron to complete the façade of the Blaj Cathedral was eight hundred florins. ${ }^{69}$ The concept of foundation appeared at the 1738 Blaj Synod, presided over by Bishop Klein, where the need for an educational system was first raised. The foundations, which were common in Western Europe and with the Jesuits, remained the main financial instrument to support students in Rome and other centres of the Empire and Europe in the following decades. The tradition of the alumni remained until the late eighteenth century.

\section{THE RELATIONSHIP WITH THE IMPERIAL COURT AND TRANSYLVANIAN GUBERNIUM. SOURCES OF FUNDING FOR EDUCATION}

The matter of funding the educational pursuits and the Uniate Church is significant because it helps trace Enlightenment influences to their source by following the financial aid, or perhaps the lack thereof, that they received from two sources: the Habsburg Court and, later, the Transylvanian Gubernium.

Aron maintained a healthy relationship with the Habsburg Court. The memorandum he sent on the state of the Union to Maria Theresa is very positive towards the Court. The extensive letter mentions that the Uniates have been faithful to the Empire since the peace of Karlowitz. It informed the Empress about the problems the Uniate Church had experienced with the schismatics, the Orthodox population that had increasingly become recalcitrant. The letter's purpose appears to be to reinforce the Church's loyalty in the context of conflict with the Orthodox, attempting to reassure the supporting Empress that the Church was not reverting to the schismatic religion. It also reiterates Aron's willingness to continue not only the cause of Catholicism in Transylvania, but also the furtherance and support of the Monarchy. ${ }^{70}$ Moreover, in 1756 (during the Seven Years War) Aron organized and

\footnotetext{
${ }^{68}$ ANR-CJ, 600/410, Blaj, 11 July 1763.

${ }^{69}$ ANR-CJ, 600/116, Sibiu, 22 December 1749.

${ }^{70}$ ANR-CJ, 600/308, Blaj, 23 July 1759.
} 
provided the Empress with a company of hussars-Hungarian cavalry ${ }^{71}-$ which was led by a member of Aron's family. ${ }^{72}$

Maria Theresa's and the Court's response was to render financial assistance to the activities of the Church and Aron's initiatives. The advances Aron made in schooling and the printing press were incredibly quick, within a span of twelve years and with little basis to build on. Departing from a primitive community to one with fifty-five schools required a powerful funding campaign. The differences between the Orthodox Romanian parishes (very small and made of wood) and the Uniate Romanian ones (increasingly large, using stone and baroque architecture) are illustrative of the opportunities that Viennese and Papal sums could provide. The two centres provided funds not only to support the spread of Catholicism in Transylvania through the Uniate Church, but also in the belief touched upon previously that it was generally better to educate the Romanians in an effort to coax them out of their primitive shells, ensuring that the Uniate programme could be solidified in subsequent years.

The Uniate Church was relatively well funded and capable of sustaining its expenses, because it was supported by three main streams of income. The most important is the twenty-four thousand florins that the Church domain in $\mathrm{Cut}^{73}$ paid yearly, a domain bought by Aron. Another significant source of income was the taxes the Church was granted early on to gather from its parishioners. The right to gather taxes was confirmed during Aron's tenure: Maria Theresa conferred two decrees in 1748 and $1752 .{ }^{74}$ The third stream of income was the Habsburg funding, which provided by far the largest sum and helped build, as mentioned above, the complex in Blaj. Furthermore, the Uniate priests were exempted from paying any form of taxes to the Transylvanian Gubernium by decree of the Empress. ${ }^{75}$

The relationship with the government contrasted with that of Vienna. The Transylvanian Gubernium was comprised of the four precept religions and dominated by Calvinists, which perceived the Uniates as the Monarchy and Papacy's Catholic instrument in Transylvania and, therefore, relations were tense.

\footnotetext{
${ }^{71}$ Bunea (1902), p. 267.

${ }^{72}$ ANR-CJ, 600/181, Sibiu, 23 November 1756.

${ }^{73}$ Tóth (2001), p. 238.

${ }^{74}$ ANR-CJ, documents found together as 600/110, Vienna, 18 March 1748 and 24 May 1752.

${ }^{75}$ ANR-CJ, 600/303, Vienna, 1 July 1759.
} 
They were disinclined to offer support, whether administrative, political or financial to the Uniate Church. From the evidence pertaining to funding, there is no indication of substantial financial support from the Transylvanian Government. In one letter, Inochentie Micu Klein informs the Gubernium of the progress of building of the Blaj monastery and requests help to continue the works. ${ }^{76}$ There is no indication in the letter that the Government provided funds and we cannot know whether the money was allocated. Starting with the 1780s, however, evidence of increased funds towards Uniate education appears. One such example includes fourteen thousand florins, a very high sum that the Transylvanian Government allotted to the Uniate foundations in 1802. ${ }^{77}$ Moreover, the Gubernium suggests the start of a new foundation for twenty-two talented young men. ${ }^{78}$ It is difficult to say with certainty what prompted the change, but it was perhaps due to the fact that Banffy was open to educational projects and the Uniate Church had become more grounded in Transylvanian society a century after it was introduced. As such, the Government became increasingly inclined to acknowledge the benefits it brought to cultural life and education in the region as a whole. It is also likely that the intensification of educational projects came as a result of Josephinism, principally as the schools' secularization became increasingly widespread. Furthermore, bureaucracy increased in education perhaps relative to its increase within the Empire at large. Resultantly, the Transylvanian Government had the power to conduct inspections in the Blaj schools, of which Governor Banffy informed Bishop Maior, ${ }^{79}$ and to co-sign on the appointment of the Schools' director. ${ }^{80}$ While governmental actions mirror Enlightened influences, their source can still be traced to Vienna, particularly as Emperor Joseph II-and later his brother Leopold II-reformed the monarchy's administration and education.

\footnotetext{
${ }^{76}$ ANR-CJ, 600/1452, no place or date.

77 ANR-CJ, 600/809 Cluj, 9 September 1802.

${ }^{78}$ The document is signed by the secretary of the Gubernium, Mihael Oros, ANR-CJ, 600/811, Cluj, 2 October 1802.

${ }^{79}$ ANR-CJ, 600/803, Cluj, 12 June 1802.

${ }^{80}$ ANR-CJ, 600/759-760, Blaj, 5 December 1795.
} 


\section{CONCLUSION}

Transylvanian Enlightenment within the Uniate Church in the mid eighteenth century was so fragile that any Enlightened endeavours in the Enlightenment periphery seem, by comparison, grounded in the phenomenon's core. It was promoted by a Catholic monarchy whose goal was to bring closer one of its most faraway, imperturbable and dissenting regions, which was so accustomed to autonomy, through the means of an ethnic group whose very few learned leaders saw an opportunity to rise from their state of clear and pressing backwardness. They did so at the cost of accepting the Pope's authority in order to possess a voice within an entrenched and largely Protestant political system that venerated and thrived in its status quo. At best, it can be said that Transylvanian Enlightenment flickered as varying influences fluttered. One influence was that of the paradoxical and everpresent Jesuits, who continued to push for education in the battle with the Reformation when the paradigm of European ideas was redefining the individual's relationship with religion. The other influence was that of the determined and pious absolutist Empress, who borrowed solutions to the issues of her monarchy from the debates of the French saloons that had made their way to her court. It is symbolic of how much Enlightenment in the region is merely a glimmer that the members of the Transylvanian public sphere can be easily counted on one's fingers.

However, even if the light simply shimmered, it still illuminated a society that - by the end of the seventeenth and throughout the eighteenth centuries - had very low education and literacy levels, confined to a segment of the clergy and the very wealthy. Enlightenment entered the Uniates through the pragmatic idea that they had to be educated in order for them to be able to matter in the region. The doctrine of the emancipation of Romanians through education represents the main trait of Enlightenment in their case, because awakening from ignorance through the exercise of the mind is the movement's fundamental principle. Even if the methods through which they achieved education were slow, dated and steeped in religion, the goal always surpassed them: the apothegmatic notion that Transylvanian Enlightenment came from religion in the eighteenth century is still valid. 
Aron, as ascetic and dedicated to Klein's ideas as he is commonly described, a theologian believing in his Eastern Catholic mission, focused on education for the lay population more than the Jesuits, who educated and inspired him, would. He searched for solutions within the narrow spectrum of examples available to him (the Jesuits, Rome, and Vienna). He applied them with the same purpose as the Empress and his predecessors: that is, to advance the Uniate society. He supervised the products of his educational efforts from the youngest member to the alumni in Rome and Vienna. Primarily, it represents a sine qua non foundation for an intellectual, Enlightened (albeit late) movement that is actually directly inspired by the Enlightenment's core.

Precisely because Enlightenment was so fragile in the area, this study cannot claim to be a study of the phenomenon as it took place in Western Europe and is understood by historiography today. Instead, it demonstrates that the ideas promoted by the thinkers and intellectual circles, salons and academies were powerful enough to filter through in the Habsburg's easternmost province before enlightened monarchs incorporated enlightened policies into their political and ideological agendas. It also demonstrates that actions were taken towards education and the beginning of a public sphere forty years before the Transylvanian School initiated their activities, filling an unexplained gap between Klein and the Uniate intellectuals' publishing at the end of the eighteenth century. Finally, it reinforces recent scholarship that has described the convoluted relationship between religion, monarchy, and the Enlightenment by demonstrating that, at Catholic Europe's peripheries, both Church and Monarchy were able to absorb the elements of enlightened programme that were suitable in advancing their own purpose, leaving questions about the extent of enlightened Catholicism and enlightened absolutism to be further researched in the future.

This work is licensed under the Creative Commons Attribution-Non-commercial-Share-alike 2.0 UK: England \& Wales License. This license allows for redistribution and alteration, commercial and non-commercial, as long as credit is given to the author. To view a full copy of this license, visit: http://creativecommons.org/licenses/ or send a letter to Creative Commons, 444 Castro Street, Suite 900, Mountain View. 